\title{
Pluralismo religioso e estudo crítico da bíblia: Desafios à missão, ao diálogo inter-religioso e às teologias cristãs africanas
}

\author{
Religious pluralism and the critical study of the bible: \\ Challenges to mission, to the interreligious dialogue and to the
} African Christian theologies

\author{
NADi MARIA DE AlmEIDA ${ }^{\mathrm{a}}$ \\ LUIZ JOSÉ DIETRICH ${ }^{\mathrm{b}}$ \\ VICTOR DUNNE \\ Roseane AlMEIDA DA SiLVA ${ }^{\mathrm{d}}$ \\ MARIA ANTÔNIA MARQUES
}

\section{Resumo}

O presente artigo aborda desafios, características e avanços da missão e do diálogo interreligioso, a partir de uma teologia pluralista e dos estudos bíblicos, sobre o processo de instituição do monoteísmo em Israel e no Cristianismo. Partindo de reflexões de teólogos que defendem o paradigma do pluralismo religioso como meio relevante de atuação e credibilidade dos discursos teológicos no mundo atual, apresenta características, progressos e limites das concepções oficiais, presentes nos documentos magisteriais do Vaticano II e derivadas dele. Aponta peculiaridades, avanços e barreiras das teologias cristãs africanas em diálogo com as várias religiões presentes na África, mais especialmente com as Religiões

\footnotetext{
a Pontifícia Universidade Católica do Paraná (PUCPR), Curitiba, PR, Brasil. Mestre em Teologia, e-mail: nadinadimaria@gmail.com

b Pontifícia Universidade Católica do Paraná (PUCPR), Curitiba, PR, Brasil. Doutor em Ciências da Religião, e-mail: luiz.dietrich@pucpr.br

c Catholic University of Eastern Africa (CUEA), Nairobi, Kenya. Doutor em Divindade, e-mail: vdunnesps@gmail.com

d Faculdade IniBF, Paraíso do Norte, PR Brasil. Mestre em Educação, e-mail: roseane12_01@hotmail.com

e Instituto Teológico de São Paulo (ITESP), São Paulo, SP, Brasil. Doutora em Ciências da Religião, e-mail: ma.antoniacbv@yahoo.com.br
} 
Tradicionais Africanas, comparadas a uma perspectiva pluralista. Nas reflexões teológicas há progressos, mas ainda falta um longo caminho a percorrer para chegar a uma atitude concreta de ações que refletem o pluralismo religioso. O caminho do diálogo inter-religioso e da visão pluralista é imprescindível, caso se queira tornar o discurso teológico relevante no mundo atual. Nesse sentido, nossa proposta é aumentar o diálogo entre teólogos e biblistas e, a partir disso, ousar mais, revendo e relendo, a partir dos estudos críticos da Bíblia à luz da arqueologia recente, o processo de constituição das teologias dentro da Bíblia e também das doutrinas, teologias e dogmas no período pós bíblico e ao longo da cristandade. Uma maior aproximação entre Teologia e Bíblia, nesse momento, pode contribuir para que consigamos ver a Bíblia, nossos dogmas e doutrinas, com sua real relatividade e nos tornemos mais humildes na relação com outras religiões e culturas. Assim, nos reaproximaremos de Jesus de Nazaré, que testemunhou sobre o Mistério Maior, ensinando a buscá-lo, encontrá-lo e a experimentá-lo em todas as conjugações e em todas as potências do verbo amar, fazendo-o crescer em todas as culturas e em todas as religiões, a começar pela nossa.

Palavras-chave: Missão. Diálogo Inter-religioso. Pluralismo religioso. Teologias Cristãs Africanas. Estudo Crítico da Bíblia.

\section{Abstract}

This article addresses the challenges, characteristics and advances of mission and interreligious dialogue from the perspective of a pluralist theology and a scriptural analysis of the process of the institutionalization of monotheism in Israel and Christianity. It starts with the reflections of those theologians who present the paradigm of religious pluralism as a credible and relevant way of conducting theological discourses in the world today. Then the study communicates the attributes, the developments and the limits of official ecclesial conceptions present in and derived from the teaching and documents of Vatican II in relation to interreligious dialogue. Next it points out the features, developments and limitations of African Christian theologies in dialogue with the various religions present in Africa, especially with African Traditional Religions, in the context of a pluralistic perspective. The article notes progress in theological reflections, and it shows there is still a long way to go in order to reach a perspective which elicits activity that reflect religious pluralism. It concludes that the path of interreligious dialogue and the pluralistic view of religion are essential if one wants to make theological discourse relevant in today's world. To achieve this, it proposes that it is necessary to increase the dialogue between theologians and biblical scholars, and from this to dare to review and re-read, from the critical studies of the Bible in the light of recent archeology, the process of the constitution of theologies within the Bible, and also, of doctrines, theologies, and dogmas in the post-biblical period and throughout Christendom. The work hopes to show that a closer relationship between Theology and the Bible at this time will do much to enable us to see the real relativity of the Bible, Christian dogmas and doctrines, and so help Christians to be more humble in their relationship with other religions and cultures. Jesus of Nazareth testified about the Great Mystery and taught his followers to seek it and find it above all in the experience of His love for them, and then he called on them to make his message have an impact on all cultures and religions, starting with their own communities.

Keywords: Mission. Interreligious Dialogue. Religious Pluralism. African Christian Theologies. 


\section{Introdução}

Um dos objetivos do Diálogo Inter-Religioso (DIR) é enriquecer mutuamente os participantes do diálogo com informações e inspirações sobre valores em que acreditam e praticam, buscando contribuir para a paz entre as religiões e seu engajamento na construção de um mundo fraterno, justo e solidário.

Entretanto, o encontro dos diferentes, quando a diversidade é percebida como diferença cultural e religiosa entre culturas e religiões, muitas vezes provoca abalos naquilo que cada sistema cultural convencionou como característico do humano. A gama de atitudes geradas por essa percepção pode ser aglutinada em torno de três reações: exclusivista, inclusiva e pluralista.

A atitude exclusivista é a crença de que fora do sistema próprio de uma religião ou de uma cultura, não há possibilidade de salvação. Uma percepção exclusivista de fé não aceita as diferenças e, muito provavelmente buscará imporse como verdade universal e absoluta. Seria o que Fornet-Betancourt (2007, p. 22) qualifica como "colonização de almas" e "demonização dos sistemas religiosos autóctones". Esta perspectiva estabelece uma hierarquia entre as religiões e as culturas, na qual as outras sempre estarão algum patamar abaixo da sua. Por isso, busca converter ao outro para poder conviver com ele.

Hoje, com o avanço da consciência dos direitos humanos e da importância da diversidade cultural e religiosa é inaceitável pensar em fazer missão com uma atitude exclusivista. Pois, como praticada na era da cristandade, e em graus variados até hoje ${ }^{1}$, essa concepção de missão está geralmente associada a visões e projetos colonialistas, e é recheada de características autoritárias, de imposição, conquista de territórios e almas para uma igreja de mãos dadas com a opressão escravagista, discriminatória e impositora de estruturas imperiais.

A partir do Concílio Vaticano II parte da Igreja Católica Apostólica Romana tomou nova atitude e novo rumo, voltando às fontes; com o entendimento de que

\footnotetext{
${ }^{1}$ Por exemplo, certas vertentes católico-romanas pré-vaticanas recorrentes, como na Dominus Iesus, e cristãs reformadas ou evangélicas, comumente chamadas de fundamentalistas, proselitistas ou conversionistas, para as quais sem a fé explícita em Jesus Cristo e/ou a pertença a uma Igreja, não há possibilidade de salvação. Seguem o paradigma oficializado no Concílio Ecumênico de Florença, em 1442: Extra Ecclesiam nulla salus.
} 
sua verdadeira missão, aquela originada em Jesus Cristo, é estar a serviço do Reino de Deus, que é paz, justiça e vida digna para todos os povos e culturas.

A postura inclusiva aceita que haja a presença de Cristo ou "sementes do Verbo" ${ }^{2}$ em todas as outras religiões, embora de maneira parcial, velada, escondida e misteriosamente, conhecida apenas por Deus (cf. GS 22, AG 11). Esta abordagem é um pouco mais respeitosa, porém, ainda classifica e hierarquiza as religiões e culturas, mantendo o cristianismo ocidental como referencial, como religião de alguma forma mais completa e superior em relação às outras.

A visão pluralista vai além do inclusivismo, quebrando a pirâmide e a hierarquia, as barreiras e restrições. Baseia-se na compreensão de que o amor de Deus é tão abrangente que não tem limites e se revela de diferentes maneiras de acordo com as culturas e épocas. A visão pluralista nasce a partir das muitas questões suscitadas pela percepção das diferenças, da consciência e do respeito aos Direitos Humanos e considera a experiência de diferentes tradições religiosas.

Este artigo defende o diálogo e o respeito, que a atitude dialógica inclui, como a ferramenta e o ponto de partida na aproximação a qualquer religião e cultura. Aponta os desafios à missão e ao diálogo inter-religioso a partir da perspectiva pluralista, assinalando a necessidade de aprofundamentos dessa perspectiva a partir da consideração dos estudos críticos da Bíblia e das contribuições da chamada nova arqueologia no mundo bíblico.

Em um primeiro momento elenca alguns teólogos que defendem uma visão pluralista e fazem um trabalho relacionado ao diálogo Inter-religioso (DIR) do Cristianismo com as religiões. No segundo momento, procura ver como aparece o conceito de missão e DIR nos documentos da igreja do Vaticano II e nos que o sucederam, apontando características e limites das concepções oficiais presentes nos documentos quando comparadas às propostas pluralistas. E por último, procura mapear teólogos e teologias cristãs africanas, suas características, avanços e limites ante as Religiões Tradicionais Africanas (RTAs). Busca ver os pontos de convergências e de apreciação tanto da cultura como das religiões

\footnotetext{
${ }^{2}$ Essa expressão remonta a Justino, o filósofo, teólogo e apologista nascido em Flavia Neápolis, uma cidade romana na região da antiga Siquém, na Galileia, que por volta dos anos 160 referia-se às sementes do verbo, "Lógos Spermatikós" ou "Spermatikós Lógos" em grego, "Semina Verbl" em latim, aludindo com isso àquela parte da razão de todo o ser humano que o impulsiona a buscar verdade e a transcendência.
} 
tradicionais, com comentários de teólogos, investigadores e pesquisadores do assunto na África.

Como observação conclusiva, propõe ampliar a discussão de um aspecto que está na raiz dos posicionamentos exclusivistas, inclusivistas e pluralistas, que interfere grandemente nas relações ecumênicas e Inter-Religiosas: o peso das doutrinas na pré-conceituação da Bíblia, de Deus, do Cristianismo e das outras religiões. Tais doutrinas e dogmas são determinantes do posicionamento frente à diversidade cultural e religiosa. Por isso, sua discussão, reavaliação e releitura, a partir da abordagem crítica e decolonial da Bíblia à luz da arqueologia recente, são imprescindíveis nas reflexões sobre a missão e o Diálogo Inter-Religioso.

\section{Teólogos / teologias pluralistas}

Teólogos pluralistas levantam questões tais como: é a nossa religião a única verdadeira? A diversidade de culturas e de religiões também foi desejada e criada por Deus? Deus está presente, sem diferenças de grau, em todas as religiões? A concepção da teologia pluralista se forma a partir de um processo que a leva a responder sim a estas questões.

Swidler (1988, p. 38) afirma que o primeiro objetivo da teologia do pluralismo religioso é o reconhecimento das outras religiões e o respeito mútuo. $O$ Espírito não é limitado a uma religião, mas opera por meio das diferentes religiões e culturas. De acordo com ele "o que é espiritual sempre vem da mesma fonte Divina".

Shorter (1998) sugere que o pluralismo religioso coloca para a Teologia Cristã o desafio de aprofundar a compreensão da salvação oferecida a todos. Além disso, para um diálogo frutífero é necessário, quando em outras culturas, aprender bem a língua do povo, seus costumes e suas tradições culturais e religiosas. Um desafio e uma exigência para todos os que se engajam em missão no mundo contemporâneo.

A atitude pluralista é mais aberta ao diálogo, evita a discriminação, a hierarquização, a imposição, a intolerância e outras violências cometidas em nome de um Deus e de uma Revelação tidos como únicos verdadeiros. Para que essa diversidade seja fonte de humanização e enriquecimento cultural e espiritual, é necessário que o encontro dos diferentes seja mediado pelo diálogo. Um diálogo 
genuíno é uma atitude de escuta atenta com interesse, respeito e apreço que, segundo Paulo Freire, ajuda a refletir sobre a própria realidade, quando as pessoas colocam o objeto a ser conhecido na mesa e como iguais "se encontram em torno dele e através dele para fazer uma investigação conjunta" (FREIRE, 1987, p. 44).

Segundo o pluralismo religioso, os tempos modernos não admitem posições hierárquicas e linguagens discriminatórias. Conforme o teólogo jesuíta americano, Roger Haight;

em nenhuma outra época as pessoas tiveram tanto senso da diferença dos outros, do pluralismo das sociedades, das culturas e das religiões, bem como da relatividade que isso implica. Já não é possível a centralidade da cultura ocidental, a supremacia de sua perspectiva, ou o cristianismo como a religião superior, ou o Cristo como o centro absoluto em relação ao qual todas as demais mediações históricas são relativas (HAIGHT, 2003, p. 384-385).

Dupuis (1997, p. 528) afirma que "o pluralismo religioso de princípio se fundamenta na imensidão de um Deus que é Amor". Assim também Panikkar (1998, p. 166) alega que a diversidade religiosa é uma riqueza da experiência humana. Esse pluralismo "pode ser expressão da vontade mesma de Deus que tem necessidade da diversidade das culturas e das religiões para melhor manifestar as riquezas da plenitude de verdade que coincide com o Mistério mesmo de Deus" (GEFFRÉ, 2003, p. 14). A partir desta pluralidade "somos convidados a pensar na possibilidade de um pluralismo de princípio que dependeria do próprio designo de Deus" (GEFFRÉ, 2004, p. 135)33.

A respeito disso, Teixeira (2010) assegura que a "tomada de consciência do pluralismo de princípio implica, necessariamente, uma desabsolutização do cristianismo", pois o "Reino de Deus se faz também presente através da atuação de outras tradições religiosas. Os 'outros' também participam da realidade do reino de Deus" (TEIXEIRA, 2010, p. 183-184). E, nesta linha, Schillebeeckx sinaliza que a verdade se encontra mais no conjunto das religiões do que em uma única, pois Deus se manifesta na vida da humanidade criativamente e de variadas formas (2012, p. 175).

\footnotetext{
${ }^{3}$ Existe o "pluralismo de fato" que diz respeito à diversidade das religiões existentes as quais são diferentes de fato, no entanto Geffré (2004) e outros teólogos como: J. Dupuis (1997), Roger Haight (2003), E. Schillebeeckx (2012), acreditam e defendem um "pluralismo de princípio" o qual seja a vontade de Deus que, no princípio, criou as diferenças.
} 
Segundo Geffré (2004, p. 131), "se podemos falar legitimamente de uma virada hermenêutica da teologia, é em grande parte porque o pluralismo religioso exerce praticamente a função de um novo paradigma teológico". Para a teologia pluralista, a diversidade religiosa e cultural, a pluralidade no mundo é parte da criação e da vontade divina (GEFFRÉ, 2013, p. 52). Ela compreende que Deus está presente em todas as culturas e religiões, de maneiras diversas e com nomes e teologias diversas, e que como um ser amoroso que colocou caminhos para a salvação em todas elas. Isso confere igual dignidade a todas as culturas e religiões. Por isso, Geffré (2004, p. 131) aporta que "à luz deste pluralismo religioso que somos convidados a reinterpretar algumas verdades fundamentais do cristianismo". O paradigma pluralista ao aceitar, reconhecer e respeitar as diferentes religiões, também reconhece e afirma a relatividade das formas religiosas. Por isso nos propõe o desafio de uma "virada hermenêutica".

O teólogo espanhol Andrés Torres Queiruga (2010, p. 139) alega que a base e o princípio do diálogo é a "convicção de que todas as religiões são reveladas" e que consiste, portanto, em "reconhecer e acolher a presença divina reveladora e salvadora" nelas. Essa visão dissolve certezas absolutas em relação a uma ação salvadora de Deus apresentada como única verdadeira e absoluta, oferecida como caminho singular para se chegar a Deus e à salvação. Leva em conta que a religião é parte integrante da cultura (QUEIRUGA, 2010, p. 147). Afirmações como estas de Geffré e de Queiruga, basilares para a compreensão do pluralismo religioso e sua proposta teológica, revelam a necessidade de uma leitura crítica da Bíblia para dar fundamento à concepção de Deus, de revelação, de missão e de salvação dentro da teologia pluralista.

Entretanto, deve ser notado que um impulso importante ao inclusivismo e à abertura da fresta que levou à teologia cristã pluralista foi o reconhecimento e as afirmações positivas em relação a outras tradições religiosas dados no Concílio Vaticano II; que apesar de reservado e tímido em certos aspectos, lançou-se ao avanço e à abertura nas reflexões teológicas em relação a outras tradições religiosas e culturas. É o que será abordado na próxima seção. 


\section{Missão e diálogo inter-religioso nos documentos do Vaticano II e depois}

No Concílio Vaticano II a teologia da missão assumiu uma nova visão ${ }^{4}$ : de eclesiocêntrica passou a reinocêntrica. No entanto, embora tenha aberto as portas ao falar da presença verdadeira e santa em outras tradições religiosas (cf. NA 2), não foi muito além, uma vez que não ousou falar da revelação de Deus nas culturas e povos. Contudo, o Vaticano II buscou superar o exclusivismo optando pelo inclusivismo. Com isso, estimulou a reflexão teológica a dar passos na direção do pluralismo religioso. Podemos perceber nos documentos conciliares e pósconciliares o desenvolvimento e o alargamento dessa abertura ao reconhecimento da presença e revelação de Deus nas religiões. Pedreira (1999, p. 49) lembra que “foi Karl Rahner, com sua tese do cristianismo anônimo, e o Concílio VAT II que irão [...] abrir as janelas para que os ares do diálogo venham arejar a teologia católica das religiões". Por isso Pedreira acredita que, no que se refere a esta questão, Rahner representa "o pensar teológico e o VAT II o pensar da Igreja" (1966, p. 49). No entanto, nesta reflexão, tratar-se-á apenas dos conceitos de missão e DIR em alguns documentos do Vaticano II e em alguns que o sucederam.

A missão aos povos foi tema de debate no Concílio Vaticano II. Havia uma grande movimentação em torno da práxis missionária - devido à fermentação das lutas anticoloniais - quando o Papa João XXIII anunciou o Concílio. O momento estava pontilhado de crises e tensões que se refletiam nas práticas da missão católica romana da época. A igreja estava vivendo um momento que demandava mudanças radicais, porque o modelo de missão antiga já não cabia no contexto moderno.

No Concílio Vaticano II, a Igreja Católica Romana descobre sua vocação de estar a serviço da missão do Reino de Deus e não o contrário. Missão de diálogo fraterno e de busca dos valores do reino de paz, justiça e dignidade para toda humanidade. Essas reflexões teológicas tiveram um avanço a partir do Vaticano II

\footnotetext{
${ }^{4}$ Havia duas visões contrastantes na teologia católica das religiões na época que antecedeu o Concílio Vaticano: "a teoria do cumprimento", que negava qualquer valor salvífico nas religiões e "a teoria que acreditava na "presença do mistério de Cristo em outras religiões". É interessante ver nos textoschave do Vaticano II que a visão do Concílio foi além da teoria do cumprimento para afirmar um papel permanente das várias tradições religiosas no plano de salvação de Deus.
} 
e vêm se avolumando a partir da fresta aberta. Isso hoje fica ainda mais claro quando se põe atenção na convocação do Papa Francisco à “conversão pastoral” e a "uma igreja em saída” na Evangelii Gaudium (EG).

Ao olharmos como aparece o conceito de Diálogo Inter-Religioso (DIR) no Vaticano II e depois dele, vemos que praticamente todos mantêm uma posição inclusivista. O decreto Ad Gentes (AG, sobre a atividade missionária da igreja), introduz um novo entendimento em relação às outras religiões, reconhecendo valores e elementos religiosos como preparação para receber o Evangelho. A missão é compreendida como testemunho de vida, diálogo e presença de caridade (AG 10-12). A constituição dogmática Lumen Gentium (LG) fala de uma "igreja povo de Deus", peregrina, que caminha buscando a realização do Reino de Deus no mundo; a constituição pastoral sobre a igreja no mundo de hoje, Gaudium Et Spes (GS), chama a dialogar com o mundo; na declaração sobre as relações da igreja com os não cristãos, Nostra Aetate (NA), o cristianismo deve com prudência e caridade, em diálogo e colaboração com membros de outras religiões, testemunhar sua fé. Deve também abrir-se aos debates teológicos sobre a salvação em outras religiões e o papel da igreja nesse contexto; a declaração sobre a liberdade religiosa Dignitatis Humanae (DH), reconhece a liberdade de todas as pessoas de buscar Deus e a verdade sem coerção. Assim, o Concílio revisa e rejeita a atitude colonialista da missão, ao voltar às raízes, às fontes da igreja primitiva; para uma reflexão bíblico-teológica da ação missionária da Trindade. Essa é a dinâmica da salvação; a missão que segue a metodologia da Missio Dei.

Segundo Pedreira (1999, p. 57), "o VAT II desempenhou um papel fundamental para a teologia católica das religiões"; avançando "de um pessimismo condenador para um otimismo salvífico acolhedor"; abrindo as "comportas" e dando "livre curso aos anseios de novas posturas na relação do cristianismo com as religiões não cristãs".

$\mathrm{Na}$ Gaudium Et Spes percebemos a ampliação da compreensão da ação salvífica do Espírito de Deus que abre a todos a possibilidade de acesso ao mistério pascal:

E isto vale não apenas para aqueles que creem em Cristo, mas para todos os homens de boa vontade, em cujos corações atua a graça, de maneira invisível. Como Cristo morreu por todos, todos são chamados a participar da mesma vida divina. Deve-se admitir que o Espírito Santo oferece absolutamente a todos os seres humanos a possibilidade de se associarem ao mistério pascal, de maneira conhecida somente por Deus" (GS 22). 
O Concílio reconhece que há elementos "verdadeiros e santos" nas religiões não cristãs (NA 2); "formas de busca de Deus" (AG 3); "reflexos, não raramente autênticos, da verdade que ilumina todos os seres humanos" (NA 2).

Em se tratando de missão requer que os missionários

Para poderem dar frutuosamente este testemunho de Cristo, unam-se a esses homens com estima e caridade, considerem-se a si mesmos como membros dos agrupamentos humanos em que vivem, e participem na vida cultural e social através dos vários intercâmbios e problemas da vida humana; familiarizem-se com as suas tradições nacionais e religiosas; façam assomar à luz, com alegria e respeito, as sementes do Verbo neles adormecidas... (AG 11).

A porta aberta pelo Concílio ao DIR deu continuidade ao desdobramento do magistério da igreja mediante documentos pós Vaticano II (PEDREIRA, 1999). Entre eles Pedreira (1999) destaca o Evangelii Nuntiandi (EN), o Redemptoris Missio (RM) e o Diálogo e Anúncio (DA).

EN (53) destaca que a "Igreja respeita e estima" as religiões não cristãs, "porque elas são a expressão viva da alma de vastos grupos humanos. Elas comportam em si mesmas o eco de milênios de procura de Deus". No entanto, aponta que essa procura é "incompleta, mas muitas vezes efetuada com sinceridade e retidão de coração". Reconhece que "elas possuem um patrimônio impressionante de textos profundamente religiosos; ensinaram gerações de pessoas a orar; e, ainda, acham-se permeadas de inumeráveis 'sementes da Palavra"”.

RM número 10 aponta que a "universalidade da salvação em Cristo não significa que ela se destina apenas àqueles que, de maneira explicita creem em Cristo e entram na Igreja"; a graça misteriosa ilumina a todos. No entanto, RM 55, assim como nos documentos do Vaticano II, Unitatis Redintegratio 3 e AG 7, apresenta um tom de eclesiocentrismo e de superioridade da Igreja Católica Romana em relação a outras religiões. Segundo Pedreira (1999, p. 70), mesmo que o Concílio tenha superado esse eclesiocentrismo, nos documentos ainda é forte seu "cristocentrismo" e seu projeto "eclesiocentrado", especialmente em Redemptoris Missio.

O documento Diálogo e Anúncio, afirma que "o diálogo é parte indissolúvel da missão da Igreja". O documento 
questiona toda pretensão a qualquer tentativa de monopolização da verdade cristã, pois 'a plenitude da verdade recebida em Jesus Cristo não dá aos cristãos a garantia de ter assimilado de modo pleno esta verdade. Em última análise, a verdade não é algo que possuímos, mas uma pessoa por quem nos deixamos possuir' (PEDREIRA, 1999, p. 70-71 citando DA 49).

Ainda assim, como no caso das "sementes do Verbo" (AG 11), a referência segue sendo o cristianismo, reconhecendo-se nas outras religiões somente aquilo que pode ser posicionado dentro do Cristianismo, tido como a única religião completa e verdadeira.

E há também contradições nos documentos. Por exemplo, DA número 33 afirma um papel absoluto da Igreja no processo de salvação da humanidade como "Sacramento Universal de Salvação" e mais à frente no número 41 relativiza esse papel incondicional da Igreja quando admite que no diálogo "pode nascer a decisão de deixar uma situação espiritual ou religiosa anterior, a fim de se dirigir a outra" (DA, 41).

Hoje o diálogo deve ser parte constituinte do modo de ser cristão. 0 desenvolvimento tecnológico na comunicação e nos meios de transporte nos tempos modernos tem a vantagem de aproximar as pessoas. Consequentemente, torna-se praticamente impossível para os indivíduos permanecer ignorantes e indiferentes a outras religiões, tradições e culturas.

Em suma, ao se pôr em direção ao outro é preciso “descolonizar a mente". Esta é a proposta do Papa Francisco para uma “Igreja em saída”. Pois, a missão desde o início tem caráter universal (cf. Mt 28,19), e não de imposição. O “ide” de Jesus não significa "invada”, o “ide” de Jesus significa "ame” universalmente. 0 amor é contagiante, respeita, acolhe, é capaz de ver valores, há liberdade para fazer e receber correções, dar e defender opiniões. Um convite à interculturalidade onde há um tratamento igualitário entre as culturas, onde as partes se enriquecem mutuamente. O Espírito sopra onde quer e, segundo Brighenti (2013, p. 99-100), “o Vaticano II fez-nos tomar consciência da presença e atuação do Espírito, para além das fronteiras da Igreja”, sendo companheiro de caminhada a todas "as pessoas de boa vontade, pertencentes a outras Igrejas ou outros credos, ou simplesmente professantes de um 'humanismo aberto ao Absoluto' (Populorum Progressio, 42)". Para que isso aconteça precisamos somar 
forças para promoção da libertação de todos, dando as mãos colaborando uns com os outros para o bem comum.

\section{Teologias cristãs africanas e pluralismo religioso: características, avanços e limites}

Após o Concílio Vaticano II, o pluralismo religioso recebeu um reconhecimento positivo na Igreja Católica Romana na África. Por exemplo, as Religiões Tradicionais Africanas (RTAs) são consideradas hoje como uma verdadeira experiência religiosa do povo africano em seu encontro com o Divino. Em Africae Terrarum, n. 8, o Papa Paulo VI pede que haja uma troca de significados entre o Cristianismo e as RTAs. Ele reconhece que os africanos têm uma expressão religiosa correta e exclusivamente africana. Como resultado, a teologia deve ser feita a partir de uma experiência de vida concreta e contextualizada. Destarte, na aproximação da pluralidade de culturas e religiões africanas somos desafiados e desafiadas a ter uma visão cósmica e uma atitude de abertura em relação a estas formas criativas e diversificadas de se aproximar de Deus (RICHARD, 1975, p.135).

Em relação às RTAs, as teologias Cristãs Africanas buscam "compreender a mensagem cristã em um contexto social" africano e objetivam "ver a mensagem de Cristo" encarnada expressa à maneira e em categorias e "padrões de pensamento" africano, em diálogo de apreço e respeito para com as RTAs (SHORTER, 1998, p. 64).

As RTAs chamam atenção por compartilharem uma atitude "notoriamente tolerante, inclusiva e acolhedora de outras tradições religiosas" (FALOLA, 1988, p. 5). Segundo Falola (1988, p. 5), na questão do pluralismo, as RTAs dão uma lição de respeito e aceitação, uma vez que estão sempre abertas ao diálogo.

As teologias cristãs africanas, na tentativa de avançar no diálogo da teologia cristã com as RTAs, apontam temas comuns para uma possível correlação: a) o fato de os africanos acreditarem no Deus ${ }^{5}$ (riador do universo e de tudo o que ele contém; b) sua visão profundamente religiosa do universo; c) Deus, como única explicação para a origem das realidades visíveis e invisíveis no mundo; e) que é "Ele quem mantém e sustenta o universo"; f) e que esta criação não para, mas

\footnotetext{
${ }^{5}$ Deus na linguagem das RTAs refere-se ao criador, e o chamam de "Ser Supremo", aquele que está acima dos outros seres.
} 
está em um processo contínuo de crescimento e que os seres humanos são colocados no centro desse universo (MBITI, 1991, p.43).

Cardeal Arinze (1997), pondera que os temas mais comuns para o diálogo com as RTAs são: Deus o Criador, o lugar do Espírito e os ancestrais, os rituais, o sacrifício, o sacerdócio, as orações, o casamento, a vida após a morte, a vida religiosa e moral, o senso do sagrado, o respeito e visão espiritual da vida, o sentido comunitário, o espírito de família, a autoridade como sagrada e o simbolismo no culto religioso. Segundo o cardeal, por meio desses pontos em comum se faz o diálogo teológico com as RTAs.

O desafio é manter um diálogo compreensivo que enriqueça $O$ conhecimento sobre esses aspectos em ambas as partes, sem pretensões de conversão e superioridade. Que seja um diálogo entre pares, de trocas de experiências espirituais sobre a experiência de Deus, que tem diferentes maneiras de se manifestar nas culturas e nas religiões.

Mbiti (1991, p. 71) destaca que pelo fato de as religiões africanas não terem "livros sagrados" estudiosos ocidentais têm sido relutantes em considerar todos seus aspectos, porque eles não poderiam conceber nem permitir que uma religião dependente da tradição oral, como as RTAs, pudesse ser considerada uma igual. Segundo o mesmo autor, o povo africano olha para Deus como seu Pai, que os criou e como um provedor de coisas boas. Em alguns lugares ele é chamado de "Grande Ancestral”, "The Elder", "O Avô", o que significa que dEle e nEle todas as pessoas e as coisas têm sua origem. Ele é bom, misericordioso, bondoso e pode fazer tudo. É Espírito invisível e eterno, mas que as pessoas podem sentir e saber o efeito Dele no universo. No entanto, a "natureza de Deus continua a ser um grande mistério e uma grande maravilha para o povo africano" (MBITI, 1991, p. 49-59).

$O$ objetivo do culto nas RTAs é "renovar o contato e a amizade entre o visível e o Invisível". A adoração é usada para criar harmonia no mundo e na humanidade, "essa é a principal forma de um africano aproximar-se de Deus". Suas orações sempre são acompanhadas de oferendas e sacrifícios, porque eles sentem que "não devem aproximar-se de Deus com as mãos vazias" (MBITI, 1991, p. 145-146).

Tratando-se do diálogo ecumênico e inter-religioso, teólogos e teólogas percebem avanços significativos na Igreja na África. Iniciativas para promover o ecumenismo e o diálogo com outras religiões não cristãs são tomadas em 
consideração, sendo chamados a desenvolver trabalhos em conjunto para a promoção humana e pelo desenvolvimento e empenho no serviço à vida, à justiça e à paz. Logo, o Sínodo da África pede um olhar respeitoso e de estima às RTAs e a uma formação adequada sobre elas aos missionários que lá chegarem (EAf 66).

Oduyoye (1994) enfatiza que, como teólogos, devem se preocupar com o pluralismo religioso, uma vez que eles fazem teologia na África, onde a maioria da população é muçulmana e/ou praticante de alguma RTAs. Essa realidade, portanto, não pode ser ignorada. Segundo a autora, a teologia na África deve ser dialógica e pluralista.

Okure (2002, p. 63) lembra as palavras do Papa João Paulo II, “fora da Igreja Católica, não há um vazio eclesial”, ${ }^{6}$ para destacar como outras tradições religiosas podem enriquecer nossa própria vida e nos ajudar a apreciar melhor a grandeza de Deus agindo no mundo.

Wirba $^{7}$ (2009, p. 157) alega que qualquer pessoa que queira participar do diálogo inter-religioso deve “compartilhar suas próprias experiências espirituais". No diálogo de intercâmbio teológico, os especialistas buscam aprofundar sua compreensão da herança religiosa de cada um para apreciar os valores espirituais um do outro.

Houve avanços no estudo das RTAs e percebe-se que elas permeiam todo o modo de ser e compreender a existência da pessoa africana, desde a concepção até a sepultura. Envolvem tudo: o modo de viver, comer, trabalhar, dançar, rezar, oferecer sacrifícios, relacionar-se com o outro e com a natureza. Por conseguinte, as RTAs, como as outras religiões, não podem ser compreendidas somente por meio da análise de seu sistema de crenças.

Assim, a preocupação da teologia cristã africana é fazer com que a doutrina cristã seja relevante em um contexto de África. Ela é entendida como tendo uma base na compreensão das religiões, mas em especial das RTAs. Para Nyamiti (2005) a teologia cristã africana ao dialogar com as religiões na África "elabora e apresenta de maneira inculturada, uma interpretação encarnada na cultura e tradições africanas" (NYAMITI, 2005, p. 3).

\footnotetext{
${ }^{6}$ OKURE (2002, p. 63) citando L'Osservatore Romano. English Edition, January 2001, "In Him all things Hold Together: a musicological Reading of Colossian 1:15-20.

${ }^{7}$ Em seu livro, a autora apresenta informações avançadas sobre o diálogo inter-religioso com as RTAs, o Islã e as Igrejas Independentes Africanas.
} 
No entanto, após repassarmos as ideias de alguns teólogos pluralistas, os documentos do Vaticano II e o pensamento de alguns dos teólogos cristãos africanos, permanece a sensação de uma tensão e um certo "desencaixe" quando se está imbuído de uma perspectiva pluralista de fato. Teólogos pluralistas, como Geffré, assumem "uma posição equidistante tanto de um inclusivismo eclesiocentrado como de um teocentrismo radical" (apud TEIXEIRA, 1998, p. 49). Há um esforço para superar o inclusivismo, por ele estar contaminado por um certo "imperialismo cristão", porém há um cuidado para não questionar a unicidade de Jesus Cristo e desfazer o "liame único entre o evento Jesus Cristo e a manifestação decisiva e definitiva de Deus" (GEFFRÉ, 1997, p. 125), permanecendo assim num interstício "entre o inclusivismo e o pluralismo, entre o cristocentrismo e o teocentrismo" (RIBEIRO; SOUZA, 2012, p. 73). Também Dupuis (1997), de certo modo, encontra-se neste ponto. Para ele o indivíduo fora da revelação cristã também tem acesso total à salvação em Cristo, mesmo antes de ter ouvido qualquer coisa sobre Ele. Para o autor "Cristo não é apenas o final, mas também o início [...]. Cristo não pertence ao cristianismo, ele pertence a Deus. São o cristianismo e o hinduísmo, e as Religiões Tradicionais Africanas que pertencem a Cristo, embora em níveis diferentes" (DUPUIS, 1997, p. 145).

É fato que a visão pluralista incentive o respeito, uma vez que considera a outra religião como uma "terra sagrada" (Ex 3,5), uma marca de Deus a ser respeitada, preservada e protegida. Porém, ela parece mais fundada em desenvolvimentos teológicos à luz do pluralismo cultural e religioso percebido no mundo de hoje do que em uma compreensão renovada dos dados revelados e da própria revelação. Há sempre a necessidade de uma "ginástica" teológica para explicar versículos bíblicos exclusivistas como Jo 14,6: "Jesus Ihe disse: Eu sou o Caminho, a Verdade e a Vida. Ninguém chega ao Pai a não ser por mim". Aqui uma compreensão fundamentada nos estudos críticos e decoloniais da Bíblia e do próprio cristianismo pode dar mais profundidade à resposta e ancorar a visão pluralista na base da fé cristã.

Também as perspectivas do Vaticano II - embora, especialmente a Declaração sobre a Liberdade Religiosa, tenha representado uma "revisão decisiva da teoria perniciosa dos direitos exclusivos da verdade, que serviu para justificar séculos de intolerância", estabelecendo uma "certa ética do diálogo interreligioso" (GEFFRÉ, 1997, p. 117) - mantiveram-se no campo do inclusivismo. E, 
mesmo "a apresentação mais aggiornada", ou "mesmo as formulações mais renovadoras desse Concílio ficam superadas pelo paradigma pluralista" (VIGIL, 2008, p. 370). Isto acontece provavelmente porque em grande parte esta compreensão é determinada por a prioris doutrinários e dogmáticos, que num círculo auto justificador igualmente orientam a leitura e a compreensão da Bíblia. Novamente aqui emerge a necessidade de uma leitura crítica da Bíblia para quebrar este círculo e abrir novas possibilidades.

Na Teologia Cristã Africana, embora haja simpatia e abertura a aspectos basilares das RTAs, ainda há grande predominância da Teologia Cristã em detrimento da Teologia Africana. Um questionamento, embora antigo, guarda atualidade nesta questão:

Se apresenta Cristo como resposta a problemas colocados pelo homem branco, como a solução das necessidades que o homem ocidental pode experimentar, como um Salvador do mundo e numa perspectiva europeia e objeto da adoração e da oração da cristandade ocidental histórica. Porém, se Cristo aparecesse como resposta a perguntas que houvessem sido formuladas pelos africanos, como seria? Se fosse apresentado no âmbito da cosmologia africana, para a redenção do homem (sic), tal como o africano a entende, seria reconhecido pelo resto da Igreja universal? $\mathrm{E}$, se a África oferecesse seu culto e suas petições a partir dos pressupostos de sua própria humanidade total e sem inibições, seriam aceitáveis? (TAYLOR, 1963, p. 16)

Portanto, uma teologia do pluralismo religioso das RTAs deve resultar em uma visão ampliada e uma apreciação da realidade para o indivíduo e para a comunidade em diálogo. Sabendo que o diálogo é uma atitude de escuta, de abertura, de acolhimento, de respeito e de flexibilidade. Mas já é possível perceber também, que só uma leitura renovada e crítica dos textos que consideramos revelados permitirá que consigamos transformar categorias mentais e preconceitos, e elaborar uma teologia cristã do pluralismo religioso que seja pluralista em seu âmago. Esta teologia sim, nos capacitará ao diálogo respeitoso na relação não só para com as RTAs, mas para com todas as religiões do mundo, porque nos levará ao reconhecimento profundo de que somos todos radicalmente iguais diante do Grande Mistério que chamamos Deus.

\section{Concluindo: Ainda há muito por fazer e andar...}

Um dos aspectos fundamentais para um verdadeiro DIR precisa ser a compreensão de que todas as religiões têm a mesma dignidade. Todas as religiões 
- e seus textos e tradições sagradas, orais ou escritas - são de fato frutos do processo de humanização dos seres humanos de todas as culturas. Elas nascem dentro da luta para enfrentar a vida nos mais diferentes ambientes e situações do planeta e do diálogo com o mistério que cerca a existência de tudo o que existe. No entanto, muitas vezes, certas teologias e doutrinas religiosas criadas dentro do percurso histórico, social e político destas religiões constituem grandes empecilhos para uma compreensão pluralista. No nosso caso são nossas doutrinas e dogmas a respeito de Deus, da sua Revelação e da sua Palavra que constituem grandes dificuldades para o diálogo (Cf. VIGIL, 2008, p. 381).

Dogmas e doutrinas podem nos fazer confundir nossas teologias e crenças com fatos históricos realmente acontecidos. E tornam difícil olhar para o Judaísmo e o Cristianismo, e para a Bíblia, e enxergá-los como fruto de processos históricos sujeitos a todas as vicissitudes que marcam todo e qualquer construto humano. ( $O$ mesmo pode ser dito do Islamismo, de certas correntes Hindus, entre outros).

Há ainda nesse ponto um grande distanciamento entre os teólogos e os biblistas. E um diálogo entre eles seria sem dúvida de grande auxílio para os interessados em um verdadeiro DIR. As teologias, as doutrinas e os dogmas dão peso sagrado para um grande conjunto de versículos intolerantes, exclusivistas e violentos que estão na Bíblia.

Uma compreensão histórica da Bíblia e do processo de constituição da fé judaica e da fé cristã permitiria ver que estes textos e documentos foram elaborados por grupos e comunidades em situações muito específicas e com motivações muito diversificadas. Permitiria relativizar estes textos e buscar à luz de Jesus novas formas de compreender e utilizar o que ali está escrito. Para isso, precisamos superar as leituras determinadas pelas pré-compreensões doutrinárias da revelação, da inspiração e da Palavra de Deus que para muitos conferem a tais textos e às instituições deles derivadas o caráter de verdade única e universal.

Uma visão não doutrinária da Bíblia - e também do Corão e de outros textos sagrados - nos permitiria ver o que de fato estes textos são: frutos diversos da diversidade das culturas humanas em seus embates com os mistérios que cercam a vida e o viver. Poderíamos ver então os processos que deram origem às nossas ideias sobre Deus e sobre a salvação, compreender os variados sujeitos políticos, econômicos sociais e religiosos implicados nesses processos. Perceber os interesses e as motivações dos vitoriosos e as vítimas destes processos de relação 
com o Mistério. Seríamos, assim, desafiados e desafiadas a avaliar criticamente aquilo que o texto, a tradição e as doutrinas nos apresentam como Palavra de Deus e confrontar estes conteúdos com o testemunho que legamos de Jesus de Nazaré, de quem queremos ser discípulos e discípulas.

O resultado seria a percepção de que as doutrinas e teologias foram elaboradas por nós em nossa caminhada histórica, em contextos sociais demarcados por delimitações sócio culturais definidas. O Cristianismo, por exemplo, tem seu início em diversos grupos dentro do Judaísmo, na Palestina e na Diáspora. Essa diversidade se alastrará nos movimentos que, diferenciando-se e separando-se do Judaísmo, formarão os cristianismos primitivos durante os dois primeiros séculos. E seguirá na história, mesmo quando uma parte deste movimento comporá uma elaboração hierárquica, litúrgica, doutrinária, dogmática e teológica que se consolidará após a aliança com Constantino, no Cristianismo como religião oficial do império romano.

Ao olhamos esta história fica patente que a diversidade marca todos os seus momentos. Diversidade esta que já existia dentro da história de Israel, em que os autores atuais, baseados nos frutos do secular estudo crítico da Bíblia e da arqueologia mais recente, não mais referem-se à teologia e à religião de Israel no singular, mas usam o plural, e falam de "teologias" (GERSTENBERGER, 2007, p. 911), ou de "religiões de Israel", (HESS, 2017, p. 495). E o monoteísmo judaico emerge deste processo, não como uma evolução natural, do caótico para o organizado, do inferior para o superior, ou do pior para o melhor, mas resulta de um processo político-social marcado por muitas violências, hierarquizações e exclusões. A instituição da teologia monolátrica e monoteísta tanto em Israel, como também as definições da teologia monoteísta trinitária no Cristianismo acontecem associadas a projetos de poder político e imperial. O que seria revelação nesse processo? Sendo que a "Bíblia começa com uma forma de politeísmo e termina com o monoteísmo", pergunta o Pe. José Comblin, de saudosa memória: "Deus seria autor das duas concepções?" (COMBLIN, 2005, p. 26).

O Cristianismo foi plural e diversificado desde o início. Tome-se como exemplo as concepções mais afetadas pelas doutrinas judaicas tradicionais dos chamados "judaizantes" que, de certa forma, cristalizaram-se no Evangelho de Mateus, e as concepções de Paulo, mais independente das doutrinas, que estão por trás do 
Evangelho de Lucas e emergem também em Marcos. Mc, Mt e Lc, no entanto, não rompem com a teologia monoteísta judaica (BROWN, 1984, p. 37). Para eles Deus, embora compreendido como "Pai", é somente Javé. E neles o filho, Jesus, e o Espírito Santo, não gozam da mesma essência e autoridade divina. Será somente a comunidade Joanina, no alvorecer do primeiro século que identificará o Filho, Jesus, com o Pai, afirmando inclusive a pré-existência de Jesus com o Pai e como o Pai. O Espírito Santo, porém, só acederá a esta identificação no longo processo que culminará com a afirmação do dogma da Trindade, no conclave de Nicéia.

O chamado "Concílio de Nicéia" precisa, entretanto, ser visto dentro do caminho percorrido por certos grupos cristãos no processo histórico pós-bíblico. Facetas deste percurso já podem ser percebidas em escritos tardios do Novo Testamento, como as chamadas cartas Deuteropaulinas e nas Cartas Pastorais. Ali se percebe um movimento de hierarquização crescente, abafamento gradativo da liderança feminina, aceitação da posse de escravos por senhores cristãos. É nesta trilha que alguns grupos cristãos, dos finais do primeiro século em diante, realizarão uma aproximação e mesmo uma acomodação do Evangelho aos valores e às estruturas do império romano. O abandono das perspectivas proféticas e transformadoras, que condenavam a exploração dos pobres pelos ricos, a escravidão, a dominação de uns pelos outros e a discriminação das mulheres, foram substituídas por práticas assistencialistas, preparando e adaptando uma narrativa apta para funcionar como religião oficial do império romano, e posteriormente do império bizantino, inglês, espanhol, português e tantos outros. E foi basicamente na situação de religião oficial destes impérios que o Cristianismo ganhou formas de religião com rituais, textos sagrados, hierarquias, doutrinas e dogmas estabelecidos e codificados. Este percurso histórico foi bem descrito por Pablo Richard (2009).

Não estarão então, pelo menos parcialmente, contaminadas nossas doutrinas, dogmas e teologias por esta aliança com o poder? Não será consequência desta longa aliança com poderes imperiais a necessidade de impor a nossa concepção de Deus como o único Deus verdadeiro e existente? A nossa Bíblia como a única e definitiva Palavra de Deus? A Igreja Católica Romana, ou o Cristianismo como a única religião que salva? Certamente uma leitura decolonizada e decolonizadora da história de Israel, da Bíblia e da história do Cristianismo será de grande ajuda para o DIR e também, seguramente, para resgatar o coração mais sagrado, de promoção da fraternidade, da justiça, do amor e da vida do próprio Cristianismo (VIGIL, 2008, p. 
374). Assim, é possível resgatar a força humanizadora do Cristianismo contribuindo de maneira mais efetiva para o processo de humanização e de crescimento do amor dentro de todas as religiões e culturas, que deve ser o objetivo último do DIR e das Teologias Pluralistas. Para nós cristãos pode-se dizer que implica em uma espécie de refundação do Cristianismo. Agora com base em Jesus de Nazaré, aquele ser humano que com suas palavras e atos, com sua vida e sua morte, nos ensinou a amarmos uns aos outros. Aquele que com tanta coerência viveu seu ensino e anúncio. Jesus que mostrou durante a sua vida que Deus não é uma religião, uma teologia, ou uma instituição religiosa, Deus é Amor (1Jo 4,8.16). Que entendamos, então, a missão como o fazer crescer o amor dentro de nossa religião e também dentro das outras culturas e religiões que, de forma tão diversificada, colorem o nosso mundo.

Percebemos que os teólogos inclusivistas/pluralistas, assim como os pesquisadores das teologias cristãs africanas e do pluralismo religioso na África, (também inclusivistas/pluralistas), deixam perceber que a teologia pluralista exige ainda uma profunda pesquisa, para que o encontro entre a Religião Tradicional e o Cristianismo seja entendido e praticado "como um diálogo de interpelação mútua e não uma 'comparação' ou competição entre duas religiões. Este diálogo mais do que um simples encontro de duas religiões é um encontro de duas culturas que assentam sobre categorias e visões de mundo diferentes" (LANGA, 1992, p. 249). Logo, engajar-se na pesquisa do DIR e do pluralismo religioso é uma tarefa exigente, urgente e ampla, como repete José Maria Vigil, lembrando Tillich, tratase de "reescrever toda a teologia" (2008, p. 369 e 372). Implica

Vencer suas resistências, soltar amarras a crenças inveteradas, a supostas certezas, superar seu temor a supostas infidelidades em que incorreriam, precisamente obedecendo aos sinais dos tempos, pelos quais lhes fala seu próprio princípio fundante... às vezes isso significa também assumir riscos e perseguições das próprias instituições religiosas. A militância teológica tem seu custo, quando é teologia profética, quando não se trata de teologia funcional" (VIGIL, 2008, p. 380).

Mas é também uma tarefa enriquecedora que exige, especialmente dos teólogos pesquisadores e dos missionários, um conhecimento profundo da própria fé e uma abertura e aprofundamento do outro que é diferente, mas que carrega riquezas imperdíveis das graças divinas. Portanto, "tire as sandálias, o solo que pisas é Santo" (Ex 3, 5), porque todo ele e tudo nele é manifestação do Mistério da Vida. 


\section{Referências}

ARINZE, F. Meeting other believers. Nairobi: Paulines Publications, 1997.

BÍBLIA SAGRADA. Bíblia de Jerusalém: São Paulo: Paulinas, 1989.

BRIGHENTI, A. Por uma evangelização realmente nova. Perspectiva Teológica, Belo Horizonte. V. 45, n. 125, p. 83-106 jan./abr. 2013.

BROWN, R. E. A comunidade do discípulo amado. São Paulo: Paulinas, 1984.

COMBLIN, J. Quais os desafios dos temas teológicos atuais? São Paulo: Paulus, 2005.

DUPUIS, J. Towards a Christian theology of religious pluralism. Maryknoll - New York: Orbis Books, 1997.

FALOLA, T. The spread of Islam and Christianity and their impact on religious pluralism in Africa. Dialogue and Alliance, Tarrytown, New York, Universal Peace Federation, v. 2, n. 4, p. 5-18, 1988.

FORNET-BETANCOURT, R. Religião e interculturalidade. São Leopoldo: Editora Sinodal, 2007.

FRANCISCO (EG). Exortação apostólica do Sumo Pontífice: Evangelii Gaudium: sobre o anúncio do evangelho no mundo atual. São Paulo: Paulinas, 2013.

FREIRE, P. Pedagogia do oprimido. Rio de Janeiro. $17^{\mathrm{a}}$ ed. Paz e Terra, 1987.

GEFFRÉ, C. O lugar das religiões no plano da salvação. In: TEIXEIRA, F. (Org.) O diálogo inter-religioso como afirmação da vida. São Paulo: Paulinas, 1997. p. 111-137.

GEFFRÉ, C. Por um cristianismo mundial. Cadernos da ESTEF, n. 30, p. 5-25, 2003.

GEFFRÉ, C. Crer e interpretar. A virada hermenêutica da teologia. Petrópolis: Vozes, 2004.

GEFFRÉ, C. De Babel a pentecostes: ensaios de teologia inter-religiosa. Tradução de Margarida Maria Cicchelli Oliva. São Paulo: Paulus, 2013.

GERSTENBERGER, E. Teologias no Antigo Testamento. Pluralidade e sincretismo da fé em Deus no Antigo Testamento. Trad. Nelson Kilpp. São Leopoldo: CEBI/EST/Sinodal, 2007.

HAIGHT, R. Jesus, símbolo de Deus. São Paulo: Paulinas, 2003.

HESS, R. S. The religions of the people of Israel and their neighbors. In: EBELING, J.; WRIGHT, J. E.; ELLIOTT, M.; FLESHER, P. V. M. (Orgs.) The Old Testament in Archaeology and History. Waco, Texas: Baylor University Press, 2017. p. 477-502.

JOÃO PAULO II (RM). Carta Encíclica do sumo pontífice: Redemptoris Missio: sobre a validade permanente do mandato missionário. São Paulo: Paulinas, 1995. 
JOÃO PAULO II (EN). Exortação apostólica do Sumo Pontífice: Evangelii Nuntiandi: sobre a evangelização no mundo contemporâneo. São Paulo: Paulinas, 1986.

LANGA, A. Questões cristãs à Religião Tradicional Africana. Moçambique. Braga: Editorial Franciscana, 1992.

MBITI, J. S. Introduction to African religion. Dar es Salam: East African Educational Publishers Ltd., 1991.

NYAMITI, C. Studies in Africa Christian theology: Jesus Christ, the Ancestor of Humanity: Methodological and Trinitarian Foundation. v. 1. Nairobi: CUEA Publications, 2005.

ODUYOYE, M. A. Commonalities: An African Perspective. In: Third World Theologians Commonalities \& Divergences. Maryknoll, New York: Orbis Books, p. 100-104, 1994.

OKURE, T. In Him All Things Hold Together: A Musicological Reading of Colossian 1:15-20, International Review of Mission, Genebra, World Council of Churches, v. XCl, p. 62-72, 2002.

PANIKKAR, R. Entre Dieu et Le cosmos. Paris: Albin Michel, 1998.

PAULO VI (GS). Constituição Pastoral do Concílio Vaticano II: Gaudium Et Spes: Sobre a Igreja no mundo de Hoje. Compêndio do Vaticano II. $29^{\text {a }}$ ed. Petrópolis: Vozes, 2000.

PAULO VI (LG). Constituição Dogmática: Lumen Gentium: Sobre a Igreja. Compêndio do

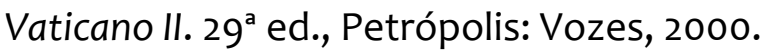

PAULO VI (AG). Decreto do Concílio Vaticano II: Ad Gentes: Sobre a atividade missionária da Igreja (1965). In: Compêndio do Vaticano II. 29ª ed., Petrópolis: Vozes, 2000.

PAULO VI (NS). Declaração do Concílio Vaticano II: Nostra Aetate: Sobre as relações da Igreja com as Religiões não-Cristãs (1965). In: Compêndio do Vaticano II. 29a ed., Petrópolis: Vozes, 2000.

PAULO VI (DH). Declaração do Concílio Vaticano II: Dignitatis Humanae: Sobre a sagrada liturgia (1965). In: Compêndio do Vaticano II. $29^{a}$ ed., Petrópolis: Vozes, 2000.

PAULO VI (UR). Decreto do Concílio Vaticano II: Unitatis Redintegratio: Sobre a liberdade religiosa (1965). In: Compêndio do Vaticano II. $29^{a}$ ed., Petrópolis: Vozes, 2000.

PAULO VI (AT). Africae Terrarum. Disponível em: <http://w2.vatican.va/content/paulvi/la/apost_letters/documents/hf_p-vi_apl_19671029_africae-terrarum.html>. Acesso em: 21 jan. 2018.

PEDREIRA, E. R. Do confronto ao encontro: uma análise do cristianismo em suas posições ante os desafios do diálogo inter-religioso. São Paulo: Paulinas, 1999.

QUEIRUGA, A. T. Diálogo das religiões e nova teologia da revelação. In: Religião e paz mundial: sociedade, teologia e ciência da religião. Belo Horizonte: SOTER; São Paulo: Paulinas, 2010. p. 119-159. 
RAHNER, K. Christianity and the Non-Christian Religions. In: RAHNER, K. Theological investigations. v. 5, Baltimore: Helicon Press, 1966. p. 115-134.

RIBEIRO, C. de O.; SOUZA, D. S. A teologia das religiões em foco: um guia para visionários. São Paulo; Paulinas, 2012.

RICHARD, G. C. Seminar education in Africa. A glimpse into the future. AFER, v. 17, n. 3, p. 129-136, May 1975.

RICHARD, P. Memoria del Movimiento Histórico de Jesús. Desde sus orígenes (años 30) hasta la crisis del Sacro Imperio Romano-Cristiano (siglos IV y V). San José, Costa Rica: DEI, 2009.

SCHILLEBEECKX, E. História humana revelação de Deus. São Paulo: Paulus, 2012.

SHORTER, A. Celibacy and African culture. Nairobi: Pauline Publication, 1998.

SWIDLER, L J. Cristãos e não-cristãos em diálogo. São Paulo: Paulinas, 1988.

TEIXEIRA, F. A Teologia do Pluralismo Religioso em Claude Geffré. Numen: revista de estudos e pesquisa da religião, Juiz de Fora, v. 1, n. 1, p. 45-83, 1998.

TEIXEIRA, F. O irrevogável desafio do pluralismo religioso. In: Religião e paz mundial. Sociedade e teologia e ciência da Religião. Belo Horizonte: SOTER; São Paulo: Paulinas, 2010, p. 173-186.

TAYLOR, J. V. The primal vision: Christian presence amid african religion. Londres: SCM Press, 1963.

VIGIL, J. M. Teologia Pluralista: os dados, as tarefas, sua espiritualidade. In: VIGIL, J. M.; TOMITA, L. E.; BARROS, M. (Orgs.) Teologia pluralista libertadora intercontinental. São Paulo: Paulinas/ASETT/EATWOT, 2008. p. 367-382.

WIRBA, K. G. The Role of Religious. Women in the Mission of Evangelization and Inculturation in Africa. Rome: Leberit Srl Press, 2009. 